\title{
THE SUGAR INSTITUTE DECISIONS AND THE ANTI-TRUST LAWS: 2
}

\author{
JAMES LAWRENCE FLY $\uparrow$
}

THE EARLIER part of this study ${ }^{1}$ was written in an effort to describe the economic and legal background of modern trade association activities, and to analyze the impact of the anti-trust laws on the program of the Sugar Institute, a typical trade association whose affairs had recently been canvassed in the Supreme Court. ${ }^{2}$ Since that article was written, the Robinson-Patman Act has been passed. ${ }^{3}$ The Act has created new areas of doubt in the law of price discrimination, and it has been claimed that it will substantially change the application of the Sugar Institute decisions, and of the anti-trust laws in general, to trade associations, perhaps even to the extent of requiring the kind of price uniformities which have previously been attacked as restraints of trade. However, although the new Act is so ambiguous that it may be construed to change the anti-trust laws as to combinations, one can hardly assume that a basic change in the law restated in the Sugar Institute case was intended or made by the Robinson-Patman Act. While more than ordinary caution and foresight will be needed in the administration and interpretation of the new Act to prevent an unobtrusive nullification of some important features of the Sugar Institute decisions, it is most unlikely that either the Federal Trade Commission or the courts will countenance the use of the new statute to justify substantial restraints and monopolistic practices by trade associations. This article will not undertake a systematic or inclusive analysis of the Robinson-Pätman Act, but an effort will be made, in discussing the specific restraints involved in the Sugar Institute

$\dagger$ General Solicitor, Tennessee Valley Authority, Special Assistant to the Attorney General in the trial of the Sitgar Instititte case.

1. Fly, Observations on the Anti-Trust Laws, Economic Theory and the Singar Institute Decisions: I. (1936) 45 YALE L. J. 1339.

2. United States v. Sugar Institute, 297 U. S. 553 (1936), aff'g, 15 F. Supp. 817 (S.D.N.Y. 1934). For further discussion of the Stigar Institute decisions and their background, see also Mermin, Sugar: A Rugged Collectivist (1936) 21 ILL. L. REv. 320.

3. Pub. L. No. 692, 74th Cong. 2d Sess. (June 19, 1936). The statute is composed of four sections: Section 1, which has six subsections, is an amendment to $\$ 2$ of the Clayton Act [38 StAT. 730 (1914), 15 U.S.C. $\$ 13$ (1934)] and is enforced by the same sanctions as $\S 2$, unamended. Section 2 of the Robinson-Patman Act is a temporary provision designed merely to make the Act applicable to the Goodyear case. Section 3 provides criminal penalties for commission of enumerated prohibited acts. Section 4 is applicable only to "cooperative association(s)" and expressly permits them to return to "members, producers, or consumers, the whole, or any part of, the not earnings or surplus resulting from their trading operations." In this article the main . interest will be with $\S 1$ of the Act and all references to it will be by Section number. 
case, to consider the extent to which the new statute may alter the application of the anti-trust laws to trade practices such as those of the Sugar Institute.

Freight Rates. The allocation of freight charges between purchaser and refiner, a keenly competitive aspect of sugar marketing, gave rise to one of the most bitterly contested issues of the Sugar Institute case. Traditional practice was to charge purchasers arbitrarily a given amount, called a freight application, for transportation of sugar to them. Occasionally this application was the actual freight rate from the nearest basing . (refinery) point. Traditionally, the refiners had used all refinery points as bases, and customers were permitted to purchase $f . o$. b. refinery when they so desired. Shipments were made by rail, by water, by truck, or by a combination of these facilities. The arbitrary freight application prevailing in a given vicinity usually bore some relation to one of the corresponding actual rates from the basing point. The problem of the refiner was not only to stabilize ultimate price, of which freight is an important part, but also to keep the prevailing application as nearly as possible at the rail rate, as distinguished from the rates by alternative routes.

Obviously, the distributing trade paying an application higher than the actual freight rate is restless. The distributor who manages to avoid the high application and effects economies in his transportation costs ' can reduce his prices, and spread his trade at the expense of his competitors. The competitors complain. The inevitable tendency in such a situation is to break down the producer's price structure to the point where the lowest available freight application rate prevails as to all sugar delivered in that general vicinity. Thus, the purchaser who has shipping and storage facilities and the natural economic advantages of location on the waterways is deprived of the benefit of his situation. Instability of prices is inherent. Competitive pressure from the purchasing side of the market is unceasing.

The responses of the individual refiners to this pressure took several forms. The anxiety of the Institute was to eliminate every concession resulting from this situation and to maintain as rigidly as possible the all-rail rate on most of the sugar moving into the affected areas, including that moved by water.

The first device established to this end was the Code provision 3(c), condemning in the name of non-discrimination "the use of differential rates on consignments or otherwise than on direct shipments over differential routes as customers' request."

Code 3(c) was supplemented by an "interpretation" reading as follows:

"General Use of Differentual Routes

Absorbing freight means the selling of transportation at less than cost, which is unsound in principle and necessarily throws an undue 
burden on the consumers at and near the primary markets. It is realized, however, that the use of differential rates on consignments cannot be prevented in all markets at all times. The customer has the right to ship over differential routes from refinery points, talking the slower service at his own cost and risk of the market during the transit period. If the quantity thus shipped is in fact inconsiderable, it should be ignored rather than break down the freight application actually paid on the preponderating quantity of sugar. If, however, sugar can be and is shipped by customers in this manner in sufficient quantity to break the market at the destination point and to render it difficult for refiners to sell their own sugar on the all-rail application, then the competition must necessarily be met. It is a question of fact in every instance, and the Executive Secretary should be fully advised, before sugar actually paying a higher rate is sold on the differential rate, of the necessity of this departure from the strict letter of the Code of Ethics." (Italics supplied)

In other words, the customer was to pay a freight application based upon rail rates regardless of the mode of actual transportation, except where the customer himself was able to take control of a barge shipment. During open-water season large distributors could and did move considerable sugar by barge. In view of this circumstance the provision, although designed to restrain any disposition to give purchasers of sugar the advantage of lower freight charges and to give the combination of refiners a stronger position in the market than they could command individually, was inefficient in operation and broke down under the competitive strain. The decree enjoined concerted action "determining transportation charges or freight applications to be collected from customers, or limiting freight absorption"; the defense waived its assignment of error as to this point, but it was a focal point of argument throughout the trial of the case, and of significance in explaining the real purpose of the activities of the association in general. The purpose and effect of the decree are to forbid any freight equalization agreement.

The defense of the code provision failed because, under the circumstances, the provision was equivalent to the fixing and, in a measure, enhancing an important part of price. The justification based on a theory of non-discrimination was patently feeble since the Sugar Institute rule protected refiners' prices against the influence of actual transportation costs, and the Institute's interpretation of its Code rule invited the refiners to ignore "discriminatory" situations until they interfered with the uniform price structure. "Absorption", after all, is a direct vehicle for price competition in a market where other elements of price are more rigidly fixed; the evidence that the Institute's opposition to absorption was based on its interest in price uniformity damaged the 
theory of fair trade on which the Institute laboriously founded its entire case. As Judge Mack said: ${ }^{4}$

"It is entirely clear that the discrimination involved in absorption did not give defendants the least concern. Their whole purpose was to prevent the breakdown of the freight structure, chiefly in the Great Lakes and Warrior River areas."

The Robinson-Patman Act can hardly change the effect of the decree as to this phase of the case. The Sugar Institute agreement governing freight applications, while superficially addressed to the principle of non-discriminatory prices which underlies the Robinson-Patman Act, was obviousiy an attempt by the combination to insulate prices against the influence of differences in the cost of transportation, an element specifically excepted from the prohibition of Section 1(a) of the Act. The Robinson-Patman Act probably impinges on the practice of freight charge absorption by an individual seller where it lessens, injures or restrains competition in addition to being discriminatory. Distinguishing between forbidden discriminations which injure competition and proper differences in prices of the individual seller promises to be the first of the tremendous tasks imposed on the Federal Trade Commission and the courts by the Robinson-Patman Act. ${ }^{5}$ In the offing lies the problem as to how far a combination may utilize the prohibitions of the statute to level out competition between members.

Since Code Section 3(c) was ineffective in practice, the refiners, turning to variants of the scheme, considered over a long period the idea of delivered prices and of zoning and basing point systems. Counsel discouraged an open agreement. But a clearly articulated system of basing point pricing 'emerged from the constant cooperation of the Institute membership. The trial court held that a finding that the system was created concertedly, although justified, was not a prerequisite to holding

4. 15 F. Supp. 817,845 (S. D. N. Y. 1934).

5. Section 2 of the Clayton Act, unamended, like $\$ 1$ of the Robinson-Patman Act, contained language to the effect that a discrimination to be unlawful must result in a "substantial" lessening of competition. This phrase, found in three sections of the Clayton Act $(\$ \$ 2,3,7)$ has been interpreted to require a showing of substantial injury to competitive conditions in the industry as a whole. See Standard Fashion Co. v. NagraneHouston Co., 25 U U. S. 346, 356 (1922); Pearsall Butter Co. v. Federal Trade Comm, 292 Fed. 720, 722 (C. C. A. 7th, 1923); Federal Trade Comm. v. Thatcher Mffg. Co., 5 F. (2d) 615, 622 (C.C.A. 2d, 1925), af'd, 272 U. S. 554 (1926); cf. American Can Co. v. Iadoga Canning Co., 48 F. (2d) 763 (C. C. A. 7th, 1930), cert. denicd, 2S2 U.S. $S 99$ (1931). In the Robinson-Patman Act, however, it is sufficient if the discrimination results in competitive injury to an individual. It may be that this latter provision will be effective to extend the ban upon price discriminations beyond the limits set by the interpretations given to "substantial lessening of competition" as found in \$2 unamended, although the terms of reference of that clause have never been tangibly bounded. 
the system illegal ${ }^{6}$ since it could, and did, find that the system was concertedly maintained. The defense bitterly disputed the contention that such a plan was either so created or maintained. The scheme, applied over limited periods in the two most competitive territories-the Great Lakes and Mississippi Valley regions-provided for all-rail rates based (as is customary in the trade) upon the refinery nearest freight-wise to the customer, on all sugar regardless of the mode of actual transportation. This was coupled with a refusal to sell $f . o$. b. refinery. The refiners shipped much sugar by water and charged the rail rates, pocketing the difference. On the other hand, the customers sought to divert the movement of sugar from the waterways to the rails, since they paid for the more rapid service anyway. Thus, savings that might be effected by water shipment, ranging as high as twenty cents per hundred-pound bag -more than the ordinary distributor's margin-were wiped out. Complaints arose from the trade, from local chambers of commerce, and in Congress.

The trial court had condemned the Institute's less drastic effort to control the influence of freight rates on delivered prices, through Code Section 3(c), as "unreasonable and therefore illegal"; thus both parts of the scheme of freight equalization were outlawed as restraints of trade. ${ }^{7}$ In the Supreme Court the defense expressly disregarded ${ }^{8}$ its assignments of error (Nos. 34, 35, 37) concerning the court's findings on Code $3(\mathrm{c})$ and the court's conclusions of law as to its illegality. The defense insisted at great length, however, that the trial court had erred in its conclusions on the facts in holding that the delivered-price system had been concertedly maintained, although the defense did not venture to urge the legality of such a system. The Supreme Court discussed the procedural and factual background of the case and concluded that the action taken by the trial court should remain undisturbed.

The economics of the basing-point system have been belligerently disputed. $^{9}$ Ideally, the competitive system should strike a balance in interregional trade very much as it would in international trade. There being no device for distant basing, a producer will naturally serve the territory immediately surrounding his plant and will come into active competition with his competitor at a point midway freight-wise. To the extent that the local producer raises his price to take advantage of his local control of the purchasing trade, he invites a competitor to invade and restrict his territory. But inter-regional trade has been no more perfect than its

6. The trial court stated that there was sufficient evidence from which an "inference" that the system was concertedly created, could be drawn if necessary. United States v. Sugar Institute, 15 F. Supp. 817, 903 (S. D. N. Y. 1934).

7. Ibid.

8. Brief for Appellants, 5-6.

9. See Burans, The Dectine of Competition (1936) 290; Fetter, The MasQUERAdE OF MONOPOLY (1931) 177, 240, 278, 292, 299, 332, 411, 463. 
analogue, international trade. Industries do not consistently grow up in perfect economic relation to competitive points of production and to the purchasing markets. In reaching out for volume, competitors are powerfully stimulated to absorb freight charges. Irregularity in the location of points of production in relation to the markets pushes producers abroad. Invasion invites counter-invasion, and by natural, if rough and approximate, competitive processes, a system of basing prices upon other companies' production points evolves without there necessarily being concert of action. Thus for short periods individual price policies may approximate basing point results for an entire industry. But the case where a seller refuses to use his own plant as a base for local sales is seldom or never found in a competitive industry, and it is a fair inference from industrial experience, as well as economic theory, that basing point practices would not long survive unmodified in a market under any kind of competitive pressure without concerted action among competitors.

The steel industry, chief exponent of the basing-point system, has defended it on a variety of grounds. Basing-point pricing increases competition, it argues, and broadens purchasers' sources of supply; it protects the property investment in a number of older centers such as Pittsburgh and Youngstown, which might otherwise be at a serious disadvantage in competition. On the other hand, critics of the system point out in the first place, that it is open to question whether there is any advantage to purchasers in having available numerous sellers whose prices are uniform and inflexible. But assuming there is some merit in thus increasing the number of rival producers, the more important question remains: Does it do this in a way which results in lower prices to the consumers or merely in increased freight absorption and greater waste of cross hauling, and also possibly of selling expense?

It is generally admitted that the basing-point systems in use in many industries involve both waste and discrimination. The purchaser near a factory, but far from a basing point, is taxed by the practice to subsidize the purchaser, perhaps his competitor, near to a basing point but far from the factory; the seller located near a basing point is given a gratuitous competitive advantage against more distant rivals; economic waste is inevitable both in cross hauling and in the subsidy to highercost producers, who would be at a disadvantage in a competitive market either because of their location or their technical inefficiency.

The Sugar Institute case is the first, with the possible exception of the Linseed Oil case, where a basing-point system or other freight equalization plan maintained by agreement ${ }^{10}$ has been considered by the Supreme

10. In Jfaple Flooring Mfg'rs Assn. v. United States, 268 U. S. 563, 571 (1925), and in Cement Iff'rs v. United States, 26S U.S. 5SS, 597 (1925) the Supreme Court held that the systems were not arrived at by agreement. 
Court. While the zoning system in the Linseed case went down virtually unnoticed with the remainder of the plan, in the Sugar Institute case the delivered price plan could not ibe ignored. Possibly because of the tactics of the Institute in failing to argue the legality of the plan, the Supreme Court left much unsaid on these issues; but by its approval of the result reached by the trial court on this phase of the case, the state of the law on these crucial issues is made clearer than in any previous case.

The Sugar Institute case was a prosecution under the Sherman Act and hence the basing-point system in that case was attacked only insofar as it was established or maintained by the concerted action of competitors. The legality of the practice under Section 2 of the Clayton Act was not involved. Thus, the Sugar Institute case, which goes far toward outlawing a basing-point plan. maintained by agreement, is not wholly revealing as to the legality of a basing-point policy enforced entirely by an individual seller. As a practical matter, however, few, if any, of the basing-point systems presently in use by various industries, could be maintained without a concert of activity. Under most industrial and commercial circumstances, a basing-point plan is invariably an exercise of monopolistic power, and is enforced, even where all the agreements underlying it are tacit, by the threat of reprisals in the event of noncompliance. But the Supreme Court's unwillingness hitherto to regard dominant price-leadership as a form of monopolistic behavior ${ }^{11}$ has left open the possibility that some basing-point systems may be considered by the court to be maintained individually. In this event such a trade policy may be vulnerable under Section 2 of the Clayton Act, with or without the amendment provided by the Robinson-Patman Law.

The Robinson-Patman Act makes little, if any, change in the antitrust law as to basing-point systems. There was eliminated from the House bill a definition of the word "price" designed to make illegal any type of basing-point system and to require the f.o.b. method of sale. It is evident from the House Committee Report that the Committee had believed that this definition would end all doubt regarding the validity of a practice which it believed to be illegally discriminatory under existing law. The definition, however, was eliminated in response to objections that the subject was so complex and of such importance as to require treatment in a separate act after more thorough investigation. Whatever the significance of this elimination, ${ }^{12}$ clearly it cannot be regarded as justifying the concerted maintenance of a basing-point system contrary to the ruling in the Sugar Institute case. And it is unlikely that

11. Cf. United States v. United States Steel Corp., 251 U. S. 417,449 (1920); United States v. International Fiarvester Co., 274 U. S. 693, 708 (1927).

12. See 80 Cong. Rec. 8140, 8223, 8224 (1936). Compare, however, Mennen Co. v. Federal Trade Comm., 288 Fed. 774 (C. C. A. 2d, 1923), cert. dettied, 262 U. S. 759 (1923) with Van Camp \& Sons v. American Can Co., 278 U.S. 245 (1929). 
the elimination of the provision will be interpreted as having any effect on the validity of a basing-point system individually maintained. The new Act probably leaves the law on individual maintenance of such a system untouched also, unless perhaps the provision making price discriminations unlawful not orily if they substantially lessen competition, but also if they "injure, destroy or prevent competition with any person who either grants or knowingly receives the benefit of such discriminations or with customers of either of them," is applied so as to make it simpler to demonstrate the discriminatory character of the system. ${ }^{13}$ However, the difference between a lessening of competition generally and an injury to a single competitor is not so clearly defined, nor so tangible, as to support a difference of treatment in this situation, where lessening of competition is as plain as injuries to individual competitors, if the court is willing to face the economic facts.

The question whether a basing-point system, individually maintained, was illegally discriminatory had not been passed upon by the Supreme Court and was unsettled when Section 2 of the Clayton Act was amended by passage of the Robinson-Patman Act. ${ }^{14}$ The Federal Trade Commission's Pittsburgh-Plus decision in 1924 is the only precedent on the legality of such a system under Section 2 of the Clayton Act unamended. ${ }^{15}$ A meagre light was thrown on the Supreme Court's attitude toward the problem in its decisions in the Maple Flooring and Cennent cases. In those cases the court held that the systems were not arrived at by agreement, and considered that issue the only one before it. The Court did not comment on the validity of the systems as individually maintained. Nevertheless, the Court's reference to particular factors which might mitigate the discriminatory nature of a system was somewhat revealing on the extent to which the Court considered the systems justified under the unamended Section 2 of the Clayton Act. Thus, in the Maple Flooring case, the Court significantly noted that "the defendants quote and sell on an f.o.b. mill basis whenever a purchaser so requests," and that the freight rate "approximated closely to the actual rate from their own mill towns". ${ }^{10}$ Likewise, in the Cement case, the Court noted that "the freight rates . . . are compiled from the official tariffs ... The basing points are points of actual shipment."17

-13. $\$ 1(a)$. See also note 5, stipra.

14. Former Federal Trade Commissioner Gaskill who dissented in the Piflsburgl-

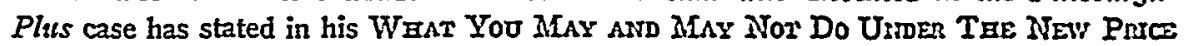
Discrmsmatron LAw (1936) 34 that under the Robinson-Patman Act all basing-point and delivered price systems are now subject to a cease and desist order if they either directly or indirectly result in a price discrimination, unless the defendant can show absence of illegal consequences.

15. In the IIatter of United States Steel Corp., 8 F.T. C. 1 (1924).

16. Maple Flooring Mffg'rs Ass'n v. United States, 268 U. S. 563, 571 (1925).

17. Cement IIfg'rs Ass'n v. United States, 268 U.S. 588, 597 (1925). 
Although its decision was not based upon a violation of Section 2 of the Clayton Act, the trial court in the Sugar Institute case indicated its belief that the two plans used by the Sugar Institute were inherently discriminatory. However, this belief was more emphatic in regard to the second plan of all-rail delivered prices coupled with the refusal to sell f.o.b. refinery than for the first plan, which did little more than limit absorptions of freight charges. ${ }^{18}$

The system condemned by the Federal Trade Commission in the Pittsburgh-Phus case was an extreme example of a system comparable to the all-rail delivered price plan, coupled with refusal to sell f.o.b. refinery, temporarily in effect in the sugar industry. ${ }^{10}$ The Commission apparently has not seen fit to consider that the substitution by the Steel Corporation of a multiple basing-point system for the condemned Pittsburgh-Plus has been in violation of its broad cease and desist order. It should be noted, however, that the multiple basing-point system of the steel industry has recently been criticized by the Commission, ${ }^{20}$ which took the position with regard to the N.R.A. Steel Code, that: "there is no difference in principle between a single and multiple point system,"

18. United States v. Sugar Institute, 15 F. Supp. 817, 856 (1934).

19. In the Matter of United States Steel Corp., 8 F. T. C. 1 (1924).

20. Report of the Federal Trade Commission to the President with respect to the basing-point system in the iron and steel industry, November 30, 1934.

21. A brief analysis of the practical operation of the multiple basing-point system, which was substituted by the iron and steel industry for the original Pittsburgh-Plus system condemned by the Commission, will throw into relief some of the objections. Under the existing multiple basing-point system, there is one primary basing point, which is Pittsburgh, with several other secondary or satellite basing points. When the base price is fixed at Pittsburgh, the prices at all the other basing points are immediately determined upon the basis of a fixed relation to the price at Pittsburgh. The relation of each point, however, is governed by the addition of an arbitrary differential to the Pittsburgh price. The differentials are not the same at all secondary basing points. The following table, illustrative of these differentials, was compiled from current quotations:

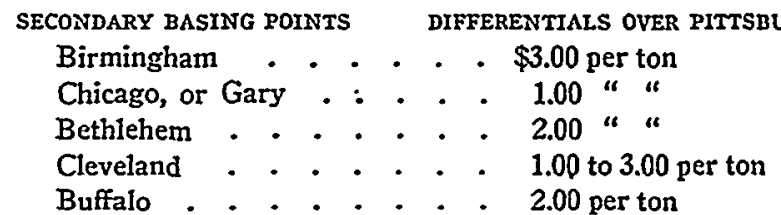

The Federal Trade Commission in the Pittsburgh-Plis case found that costs of production at some of the secondary base points, such as Birmingham and Chicago, were substantially lower than the costs at Pittsburgh; yet the base prices at Birmingham and Chicago, since the substitution of the new pricing system for the one condemned by the Commission, have consistently been higher than at Pittsburgh. This is an effective method of thwarting the operation of competitive economic forces.

Furthermore, a new facet of this problem is a form of regional discrimination which directly affects industry in the regions working under the price disadvantages of the system. When it is remembered that industries which achieve economies through pro- 
although it pointed out that the monopolistic results of basing-point pricing were somewhat ameliorated by the use of a multiple point system. The Commission was here dealing with a combination and was condemning the system as "price fixing." While it did not specifically" refer to Section 2 of the Clayton Act, it emphasized the discriminatory features of the system similar to the features that had induced the condemnation of the Pittsburgh-Plus::33

"A fundamental objection to the basing-point system of fixing prices is that such gifts of nature as the close proximity of iron ore, coking coal, and fluxing stone in the Birmingham district supplemented by Government improvement of water transportation, are withheid from the consumers by the producers to the latter's sole benefit. One of the chief unnatural effects of the basing-point system on consumers is its incidental requirement of the use of all rail transportation charges." 24

Boycott. Many refiners exercised a number of related business functions. Thus, they and affiliated companies engaged in the production of raws and in transportation, cooperage, syrup manufacture and alcohol manufacture. The Institute did nothing to disturb these multiple activities. It did, however, devote zealous-attention to members of the distributing trade who performed more than one service. The Institute by its Code condemned "the storage of sugar in warehouses in which customers or brokers are interested, or with which they are in any way affiliated." But this general disapproval of combined services was not translated into oppressive form until May 2, 1929, when, after a special meeting, the refiners wired their distributors as follows:

duction on a large scale are dependent upon a national and sometimes an international market, it is not difficult to trace the effect of the regional discrimination involved at this pricing system. For example, the fabricator located at or near a secondary basing point bearing a price differential over Pittsburgh, to the extent which he enters into competition with similar fabricators who purchase their materials from Pittsburgh, would have to absorb the price differential. Then, too, the manufacturer who further converts semi-finished steel products into finished goods, which must be sold on a national market, would always be confronted with this disadvantage. As a consequence, a prospective manufacturer searching for a new industrial site to engage in a business which uses rolled-steel products as the raw material, immediately realizes this unfavorable situation and generally governs his choice of a factory location accordingly, which means that he tries to locate at or near the primary base point.

22. S F.T.C. 1, 35 (1924).

23. Id. at 21 .

24. The Commission left no ambiguity as to its condemnation of the system if maintained by concerted action:

"In economics, as in medicine, diagnosis is fundamental. The diagnosis which the Commission makes is that the basing-point system not only permits and encourages price fixing, but that it is price fixing." 
"Please advise us by wire whether you and your affiliated interests desire to deal with is either as broker, warehouseman or merchant. Any position taken with us must be consistent with that taken by you with any of our competitors."

Two days later the refiners followed up:

"Referring to our telegram of May 2 to which we have as yet received no reply, please be advised that we cannot accept business from any person, firm or corporation until their status as broker exclusively, or as merchant exclusively, or as warehouseman exclusively has been notified to us and satisfactorily established."

On May 7 the Institute informed each member of the "recommendation of the Enforcement Committee, that no business should be accepted from any broker who had not signified his election to be exclusively broker to the satisfaction of refiner," and that no further consignments should be made to any warehouse affiliated with a broker "pending complete severance of business." This remarkable plan, whereby the producers coolly planned to reorganize the businesses of the distributors, was rebuked by the courts, and the Institute was enjoined from:

"requiring or requesting any broker, warehouse, customer, carrier, trucking concern, or any combination thereof, to elect to perform one or more such distribution functions to the exclusion of others, or to discontinue or refrain from any distribution function or to dispose of any business or property interest."

The theory of the defense reiterated the Institute's favorite slogans of open prices and non-discrimination. The argument of the Institute was that the distributors, except customers, were agents performing functions for the refiners. By performing more than one function the agent earned more than one fee. He was thus in a position to, and frequently did, extend some secret concessions to his customers, thereby reducing the ultimate market price of sugar. Brokers frequently were in collusion with the customers, and where a broker controlled a warehouse he could delay recording withdrawals from the warehouse so as to give the customer the benefit of any lower price in the interim. More easily, the customer who also maintained a warehouse was in a position to withdraw the sugar at his own choice and later record the withdrawals in such a manner as to give him a lower price or an unearned storage fee. Paradoxically enough, the greatest source of secret concession was the refiners' habit of paying customers for unearned storage of the customers' own sugar. These practices obviously militated against higher and uniform prices to the public.

The May 2 telegram, in the light of the actual subsequent enforcement of the rule there laid down, is beggared for a parallel in anti-trust 
history. "Trials," conducted, exclusively by the refiners, were held to determine the existence of "affiliated interests"; a relationship between different types of distributors to a stated degree of affinity or consanguinity constituted an offense. Iarge and small, the efficient and the inefficient, the honest and the dishonest were forced to dismantle going businesses and dispose of properties in order to eliminate business habits that led to price reductions. The effort of the Sugar Institute to segregate the functions of brokers, dealers, and warehousemen involved the simplest and most primitive kind of restraint of trade: a coercive exercise of economic power for the purpose of protecting prices against the influence of competition.

Before the Robinson-Patman Act, there was no public policy against such a combination of functions, and there is no extrinsic objection on economic grounds to the performance of multiple functions by one person. It was convenient and to a great extent customary in all phases of the grocery industry. Many small concerns could not make a living without performing more than one service. Some of the larger, over a long period, had built up heavy investments in warehousing, transportation and merchandising facilities. Many of these sugar distributors were guilty of no irregularity or inefficiency. Conceding the combination of functions to be particularly adapted to the fostering of unauthorized concessions, there is reason to believe the concession system preferable to a wasteful prohibition of combined functions, especially when enforced by boycott.

The trial court, though not unmindful of the problem of checking unauthorized rebates concealed by the combination of functions, pointed out that the refiners affected might have eliminated the irregularities as to rebates and concessions by individually abandoning their own concession habits and denied the Institute any power to require a reorganization of its customers' business. The Supreme Court affirmed the trial court's holding that the boycott was illegal, without commenting on the marketing problem to which the boycott was addressed. Meanwhile the Robinson-Patman Act has come to the assistance of the individual refiners by its prohibition of brokerage fees and allowances granted or received in interstate commerce " . . . except for services rendered in connection with the sale or purchase of goods, wares or merchandise, either to the other party to such transaction or to an agent, representative, or other intermediary therein where such intermediary is acting in fact for or in behalf, or is subject to the direct or indirect control, of any party to such transaction other than the person by whom such compensation is so granted or paid." 25

25. Section 1(c). The prohibition against brokerage allowances is not in terms qualified by the necessity that a substantial lessening of competition or compatitive injury result in order that the practice be illegal. See THE Rosnssori-PATasnsr ACT 
Although the full import of this section of the statute cannot readily be determined, it is evident that it was intended as an attack on the practice of allowing brokerage discounts to customers who do not deal through independent brokers, ${ }^{20}$ as is usually the case with the large chain stores. The sponsors of the bill in Congress apparently regarded brokerage fees in such circumstances as a major instrument for aggrandizing the power of chain-store systems. ${ }^{27}$ The statute explicitly prohibits such allowances, between buyer and seller only where no services are rendered. ${ }^{28}$ It would be reasonable, therefore, to interpret the Act as requiring in each case a demonstration that the buyer or his representative contributed some service to the transaction beyond the act of purchase. As a practical matter, of course, it would be difficult for the purchaser to prove he has rendered the seller a service as broker, unless the phrase "for services rendered" should be liberally interpreted to include any savings in cost to the seller by reason of the elimination of independent brokerage service. But it is not likely that the phrase will be so interpreted; and if the section is interpreted as its sponsors on the Judiciary Committee intended, any allowance for brokerage to a buyer or to a buyer-controlled broker in connection with the sale will be forbidden, whether or not it can be proven that tangible services as a broker were rendered. ${ }^{29}$

(The Washington Post, 1936) 35; Gasxilt, supra note 14, at 52. But the above qualification may be read into this subsection, possibly in order to save it from attack on grounds of constitutional invalidity. It could, moreover, be so interpreted in view of the stated intention to prevent "oppressive discriminations." See H. REP. NO. 2287, 74th Cong., 2d. Sess. (1936) 14.

26. Although the statute applies to brokerage paid to sellers as well as to buyers, we shall discuss only brokerage paid by sellers to buyers, the more important practice in the sugar industry. The discussion applies, pari passil, however, to the reverse situation.

27. See Phillips, The Robinson-Patman Anti-Price Discrimination Law and the Chain Store (1936) 15 Harv. Bus. Rev. 62, 66.

28. There has been some disposition to read the statute as prohibiting all brokerage allowances "except for services rendered," even where the allowance is granted to one who is not affiliated with the buyer. [See The RoBnsson-Patarax ACT (The Washington Post, 1936) 36; Legis. (1936) 50 Harv. L. Rev. 106, 113, n. 45. But cf. id. at 114, n. 47]. This interpretation requires an unintelligible construction of the Act: that in a sale by $A$ to $B$, it is illegal for $A$, the seller, to pay commissions to anyone except for scrvices rendered to $B$, the buyer. On the other hand, if it is correct, as suggested here, that the Subsection applies only to the role of brokerage allowances in the relationship of seller and buyer [and see, to that effect, speech of Chairman March of the Federal Trade Commission, Drug Trade News, Sept. 28, 1936, p. 45, col. 5] the statute must be amended to attain grammatical respectability, since it now declares it to be unlawful for any person "to receive or accept (a commission) .. . to the other party" rather than "from the other party."

29. See H. R. Rep. No. 2287, 74th Cong., 2nd Sess., (1936) 15, and the Conference Report, H. R. REp. No. 2951, 74th Cong., 2d Sess. (1936) 7, 15; and see Speech of Congressman Utterbach, s0 CoNG. Rac. 9418 (1936). This interpretation appears ques- 
It is clear, however, that the amended Act does not prohibit combining, the functions of broker and warehouseman and transportation company, and the payment of compensation to such a combine for each type of service is not affected by the statute. The Act was directed at the case where a purchaser carries on these combined functions.

The Robinson-Patman Act does not specifically refer to discounts for warehousing. However, both Sections 1(c) and 1(d) are broad enough to cover them. But since such a fee can easily be shown to be payment "for services rendered," a purchaser-warehouseman should not have the difficulty collecting fees for bona fide services even in connection with deliveries to himself that a purchaser-broker will have under this section. Section 1(d) was aimed at allowances to customers for advertising, but its language is sweeping enough to forbid allowances to customers for warehousing the stocks of the seller, unless the allowance "is available on proportionally equal terms to all other customers competing . . " Bearing in mind the necessity for giving the statute a reasonable construction, and avoiding questions of validity, it would seem that a seller may pay a customer for bona fide, independent warehousing facilities and services even though certain of the customers are not equipped to furnish the type and quantity of facilities or services required by the seller. Payment for faked services or facilities is the chief aim of the Subsection, and insofar as it may cover warehousing. it can hardly be deemed to require that every purchaser, or none, shall be accepted as a warehouseman. Where the prohibition is not in unambiguous terms (as in the case of quantity discounts beyond limits fixed by the Federal Trade Commission), the statute should not be construed to forbid customary business transactions..$^{30}$

As far as brokerage and warehousing habits in the sugar trade are concerned, it thus seems fairly clear that independent broker-warehousemen, who are not purchasers, are unaffected by the new Act; but purchasers who are also brokers, or who control brokers, while they need not abandon their brokerage business, must probably give up claims to

tionable, however, in the light of the wording of the subsection. But the courts may resort to Congressional history if they think that the statute is ambiguous.

In any event the problem will arise as to when a particular organization is so "controlled" by a party to the transaction as to bring payment of brokerage within the prohibition of the statute. It would appear that control in the sense of ability to formulate and direct policies is sufficient and that complete or even substantial stocls ownership is not requisite.

30. Interpretations should be avoided which may lead to invalidation of the provisions on the ground that "under the guise of protecting the public (they) arbitrarily" interfere with private business or prohibit lawful occupations or imnose unreasonable and unnecessary restrictions upon them." Cf. Burns Baking Co. v. Bryan, 264 U. S. 504, 513 (1924); Liggett Co. v. Baldridge, 278 U. S. 105, 113 (192S). See also Fairmont Creamery Co. v. MIinnesota, 274 U. S. 1 (1927). 
brokerage commissions on sales to themselves, thus fulfilling one of the objectives of the Sugar Institute's boycott. However, the Act would not, it seems, deprive purchasers who have warehouses of their commissions as bona fide warehousemen, as the Sugar Institute had aimed to do.

Quantity Discounts and Other Allozeances. A rule of the Sugar Institute's Code of Ethics condemned quantity discounts. The decree struck at this rule by enjoining the Institute from preventing, restraining or refusing to grant quantity or other discounts where such discounts reflect, effect or result in economies to refiners, either in direct or indirect costs.

The sugar industry never had quantity discounts as such. To a great extent discounts were secret, and varied not only with the quantity sold, but with the size and trading ability of the buyer. Discounts were not graded in definite ratio to quantity or to diminishing costs. In fact, the trial court found quantity sales brought no appreciable savings to the refiners in direct costs. $^{31}$ However, in sales to those manufacturers and distributors that can take deliveries of their sugar in carload lots direct from the refinery, as many prefer instead of ex-consignment, there are substantial savings in delivery, storage, bookkeeping, and other incidental expenses. Large purchasers other than chain stores were more likely to take deliveries in this way than small purchasers. It appears, however, that no such savings would be effected in large sales to chain stores because, in effect, the large sales in such cases usually amount, in view of the method of taking delivery, to a series of small sales to the individual stores in the chain.

On the question of indirect costs, the Court found that sales which distribute production more evenly through the year effect substantial savings to the refiners. The trial court also felt that the demand for sugar was elastic and that quantity discounts might reasonably be expected in the long run to build up production and effect certain manufacturing economies incident to a larger scale of production. The defense insisted that the only way in which the direct costs of making and selling sugar could be reduced was by making deliveries in large lots, so as to reduce handling costs ${ }_{3}^{32}$ such economies had nothing to do with quantity purchases, which often required delivery in small lots. It urged that whatever decrease in costs was incident to. producing an increased volume should be apportioned to all of the refiners' purchases rather than to the large ones, and emphasized that the same result could be accomplished by an accumulation of small orders. Their approach was not accepted.

31. United States v. Sugar Institute, 15 F. Supp. 817, 868 (S. D. N. Y. 1934).

32. Brief for Appellants 108. 
In evaluating the ruling of the courts on this question, it is important to note the limited scope of the decree itself, which enjoins the Sugar Institute from requiring its members to refuse to grant discounts in cases where such disconuts reflect, effect or result in economies. The canons used by the courts in the Sugar Institute case for judging the propriety of discounts are in general concerned with costs, and with the relation between prices and the quantity demanded. The courts favored a price policy which led to an increased volume of sales, assuming that such ai increase in volume involved savings in unit cost, either directly or indirectly, and they frowned on restraints which attempted to frustrate this increase in the physical output of sugar by preventing price cuts via discounts. The language of the decree in the Sugar Institute case seems to imply that there are situations where the trade association might permissibly limit the discount practices of its members. However, when the injunction itself is coupled with the finding of the court as to elasticity of the demand for sugar and the savings effected by quantity sales, the sugar industry can hardly hope itself to avoid the impact of the court order by rewording its discount rules. As to the significance of this provision of the decree to other industries, it may be noted that a few industries may show an inability to decrease costs with increasing demand and on that basis assert the right to restrict quantity discounts. But producers of specialties or proprietary articles, and public utilities, industries where, as price goes down, demand increases and unit costs are lowered, would have even less justification than the sugar refiners for eliminating quantity discounts.

The decree apparently did not deny the Sugar Institute power to restrain its members from some discount practices not clearly in violation of Section 2 of the Clayton Act, as the law then stood. For example, while it denied to the combination the right to ban all quantity discounts, it left it free to eliminate discounts based purely on quantity with no relation to cost savings or purely on the trade status of purchasers (of wholesalers, retailers, chain stores, etc.) where no economies were reflected, although such discounts granted by individuals were apparently legal under the Clayton Act prior to the Robinson-Patman Amendment. ${ }^{33}$

33. In MEennen Co. v. Federal Trade Comm., 2ss Fed. 774 (C. C.A. 2d, 1923), cert. denied, 262 U. S. 759 (1923), a sales policy which involved classification of the trade into wholesalers and retailers and the allowance of a greater discount to the former was held not to violate $\$ 2$ of the Clayton Act unamended. The Supreme Court in Van Camp \& Sons Co. v. American Can Co., 278 U. S. 245 (1929), disapproved part of the reasoning of the Court in the Memmen case. But see as tending to support the Memen case, S. S. Kresge Co. v. Champion Spark Plug Co., 3 F. (2d) 415 (C. C.A. 6th, 1925); National Biscuit Co. v. Federal Trade Comm, 299 Fed. 733 (C. C.A. 2d, 1924), cert. derried, 266 U.S. 613 (1924); Great Atlantic and Pacific Tea Co. v. Cream of Wheat Co., 227 Fed. 46 (C.C.A. 2d, 1915). See also Comment (1929) 42 Hnrro. I. REv. 680, 683 . 
In permitting the Institute to restrain discounts which were not illegal under the Clayton Act, the Court made an unusual concession to the freedom of a trade association to frame rules for its trade, a concession which seems mainly directed to the problem of chain store marketing. Chain stores habitually take deliveries of sugar in small quantities drawn from local consignment, a practice more costly than car-load deliveries in delivery, storage, bookkeeping and other incidental expenses. Refiners contended that these expenses offset the more theoretical savings in indirect costs incident to sales of large quantities. To justify the elimination of the quantity discount, they argued that under such circumstances fixed quantity discounts to chain stores are concessions to economic power, not responses of price to reductions in cost. ${ }^{34}$

Insofar as the decree in the Sugar Institute case permitted the Institute to bar discounts which did not correspond to economies of manufacture or distribution, it anticipated the policy of the Robinson-Patman Act. The Act excepts from its catalogue of prohibited price discriminations ${ }^{35}$ "differentials which make only due allowance for differences in the cost of manufacture, sale, or delivery resulting from the differing methods or quantities in which such commodities are . . . sold or delivered." This permissive allowance of discounts which correspond to cost differentials (saving, for the time being, the problem of measuring and allocating costs) is qualified by the power given the Federal Trade Conmission, to limit the price advantages which can be given a purchaser of large quantities. Where the Commission finds, after hearing all interested parties, that there are so few large scale purchasers that quantity discounts would give them an advantage in competition which the Commission considers "unjustly discriminatory or promotive of monopoly in any line of commerce", it is authorized to fix "quantity limits", and quantity discounts in excess of those limits are made unlawful. ${ }^{36}$

34. Query the legality under $\$ 1$ (a) of the Robinson-Patman Act of allowing a discount on a quantity basis, for such purchases. It may be urged either that an arrangement of this character is merely a subterfuge to gain a quantity discount on what are in reality small orders, especially if payment for the sugar is staggered, or that there are present no "difference(s) in the cost of manufacture, sale or delivery" for which "due allowance" may be made. In addition, this practice of warehousing the sugar for some buyers may come within the ban of $\$ 1(\mathrm{e})$ of the Act as a "service or facility" not accorded all purchasers; and from another aspect, such practices may bring the parties within the provisions of $\$ 3$ of the Act and make them subject to its criminal sanctions for granting or receiving a "rebate" that is not available to competitors of the buyer.

An analogous problem arises in connection with the granting of quantity discounts on a cumulative basis, that is, all purchases for the month or year as the case may be are totaled and the discount allowed accordingly. The difficulty of proving a savings in cost in such cases is obvious.

35. See note 37 , infra.

36. Section 1(a). Some commentators reject this interpretation, contending that the Commission is not under this clause authorized to fix the amount of the discount "but 
The test for the legality of a discount, otherwise within the prohibition of Section 1(a) of the Robinson-Patman Act, ${ }^{3 T}$ is one of costs: discounts are legal if they make "only due allowance" for economies "in the cost of manufacture, sale, or delivery" which are associated with the reason for the discount. If discounts discriminating among purchasers on the basis of trade status are considered to restrain or injure competition, they will have to be examined in the light of a cost analysis. ${ }^{33}$

merely the quantity limit to which such discount may be applicable" See Tre Rost:so:Paturan Acr (The Washington Post, 1936) 29.

37. In order for the ban of $\$ 1$ (a) of the Act to be applicable to a discrimination, three elements must concur: (a) a sale and purchase of a commodity in commerce; (b) discrimination in price "either directly or indirectly"; (c) "where the effect of such discrimination may be substantially to lessen competition or tend to create a monopoly in any line of commerce or to injure, destroy, or prevent competition with any person who either grants or knowingly receives the benefit of such discrimination or with the customers of either of them."

The above strictures should, however, be qualified on two points: (a) the burden of proof, in the sense of showing no sufficient effect on commerce, etc, is by $\$ 1(b)$ placed on the defendant and the government apparently need not prove the presence of the requisite effect on commerce or competition to establish 3 prima facic case at least before the Commission; (b) discounts which may be justified under the provisos of the Act, such as arising from "differences in cost, etc.", are clearly legal irrespective of any question of their effect on commerce.

38. Some commentators contend that such discounts are not within the prohibition of $\$ 1$ (a) because they do not "substantially lessen competition" or "injure, destroy, or prevent" it on the ground that there is no competition between purchasers of difierent status. See Gordon, The Afcaning of Sections $I$ and 3 of the Robinson-Patman AntiDiscrimination Act (1936) 22 A. B. A. J. 593. They point to the cases which under $\$ 2$ of the Clayton Act unamended apparently upheld the legality of functional classification (see note 33 supra) and contend that these are applicable to $\$ 2$ as now amended. But $\$ 2$ of the Clayton Act now outlaws discounts which result merely in individual competitive injury as distinguished from the injury to competitive conditions in the trade as a whole, which was requisite to holding discounts illegal under $\$ 2$ as unsmended. And in further defense of the view that discounts based on trade status can bring about an injury to competition, it is contended that there is competition between chain stores and wholesalers, and that to grant a discount to a wholesaler merely on the basis of his status may be effective to "injure, destroy or prevent competition" between the two, and is therefore illegal, unless justifiable as based on a difference in the cost of sales; and further, as a matter of congressional intent, that a provision specifically permitting such discounts was eliminated during the passage of the Act. See S0 Cossc. Rec. S113, S114 (1936) ; Sen. REP. No. 1502, 74th Cong., 2d Sess., (1936) 1, 5. See also Gaskilu, supris note 14 , at 30 . This construction, requiring the showing of an injury to compatition as ground for an attack on trade status discounts, is supported by the Federal Trade Commission's attitude in its complaint against the United States Quarry Tile Co. [(1936) 4 U.S. LAw WeEK 177]. There, it was alleged (par. 3 of the complaint) the defendant company discriminated in the price of its product between contractors and "wholesalers." It is pointed out that the "so-called wholesalers are in fact retailers in that they resell said tile to the ultimate consumer" and are, therefore, in direct competition with the contractor, so that granting to the wholesaler a discount denied to the 
The Robinson-Patman Act apparently adopts the conclusion of the Federal Trade Commission in the Goodyear Tire case, which had been seriously questioned as an interpretation of the unamended Clayton Act, that a difference in price is forbidden "unless it is based on a difference in" cost ... and reasonably related to and approximately no more than the difference in cost." It is not clear how exact the calculation of economies in costs must be under the new statute, and whether the Act includes what Judge Mack in the Sugar Institute case called "indirect" costs in the category of costs "of manufacture, sale, or delivery". The statute does require some kind of demonstrable correspondence between cost and discount. Of course, as the Commission remarked in the Goodyear case, "the problem is a practical one . . . [and] a discount is not to be condemned merely because it does not mathematically accord with cost differences"; 30 on the other hand, there will undoubtedly be a tendency, in administering the new Act, to ignore economies which seem remote or speculative, especially since the statute places the burden of justifying all discriminations in price on the person charged with violating the Act. ${ }^{40}$ The attitude of the Commission in the Goodyear case indicates that it may be difficult to establish that a sale to a customer who has been given a discount involves an economy in indirect costs. The Act will inevitably involve the Commission in a tedious routine of cost analysis whose results will necessarily be only approximate. There is danger that real, though intangible, economies will be classified as remote and speculative, and that the consuming public will thereby be deprived of justified price cuts. The warnings that the Act is susceptible of such interpretation can hardly be ignored.despite the assurances of the House Judiciary Committee that:

"Any physical economies that are to be found in mass buying and distribution, whether by corporate chain, voluntary chain, mail-order house, department store, or by the cooperative grouping of producers, wholesalers, retailers, or distributors-and whether those economies are from more orderly processes of manufacture, or from the elimination of unnecessary salesmen, unnecessary travel expense, unnecessary warehousing, unnecessary truck or other forms of delivery, or other such causes-none of them are in the remotest degree disturbed by this bill."

The new Act fails to distinguish between markets in which there are many competitors and markets in which there are few competitors, and

contractor injures competition between them, a fact which is alleged to make the discount illegal uniess justified by a savings in cost.

39. On the Goodyear case generally, see George, The Federal Trade Commission Decision in the Goodyear Case (April, May and June, 1936) The Dun and Bradstreer MONTHLY REVIEW.

40. Section 1 (b). 
on this ground is open to serious objections of economic policy, if its prohibition of discriminations is applied in situations where the prices preserved by the Act against the raids of large purchasers are monopolistic prices. The Act ignores the possibility that it may be in the public interest, where monopolistic price-formation is inevitable, to encourage price discrimination. ${ }^{41}$ It is evident that cautious administrative and judicial interpretation of the Act is essential to insure that the lesser evils of price discrimination are not eliminated to enhance the greater evils of fortified monopoly.

But whatever the policy of the new Act with respect to price discriminations and trade discounts, its enforcement is entrusted to the Federal Trade Commission and the courts, and not to the autonomous action of business men grouped in trade associations. The most significant holding of the Sugar Institute case was that restraints of trade could not be justified as an attempt to eliminate price discrimination, that is, to enforce Section 2 of the Clayton Act. It may be expected that the courts will view with at least, an equal skepticism trade association rules supported in the name of the non-discrimination policy of the RobinsonPatman Act, a statute broader in scope than the original Section 2 of the Clayton Act, dependent for enforcement on extensive factual investigation, and concededly susceptible to misuse for monopolistic purposes. Although, in the Appalachian Coals ${ }^{22}$ and the Sugar Institute cases, the Supreme Court indicated a willingness to uphold trade association rules insofar as they restrained acts then illegal, and perhaps some trade practices not illegal but merely inconvenient, it is extremely doubtful that the courts will hold that a trade association has powers of self-regulation coextensive with the broad and unexplored implications of the Robinson-Patman Act.

Whatever the complexities of the Act, it is clear that it was not intended to promote price fixing or other monopolistic activities. Current comments on the Robinson-Patman Act, attempt to stretch Section 1(a) to extreme lengths. It is contended that not only must prices be uniform, even to the extent of eliminating all discounts, but that open price systems, future price reporting and waiting periods are now required in the interests of equal treatment for all customers. ${ }^{43}$ Such opinions may

41. See Fly, sikpra note 1, at 1347; p. 254 infra.

42. Appalachian Coals, Inc. v. United States, 288 U. S. 344 (1933).

43. See Gordon, sipra note 3S, at 594, 598; minority report of Congressman Celler of Committee on the Judiciary, H. R. REP. 2287, Pt. 2, 74th Cong., 2d Sess. (1936) 13; cf. GaskmI, supra note 14, at 36; 48 Awnsursr 213 (August 14, 1936). The sponsors of the bill repeatedly and vehemently disavowed that the amendment was intended or would have any such effects. Thus in the conclusion of the House Committee Report, Congressman Utterback, undertaking "to correct some important misapprehensions, and even misrepresentations," stated: "There is nothing in it (the Bill) to fix prices, or 
fairly be classified as wishful thinking. No bona fide effort to comply with the amended Act and with the other anti-trust laws can include such price fixing schemes.

Consignnnent Points. Prior to 1925 refiners maintained warehouse stocks chiefly in a few important terminal or junction points for reshipment on short notice to nearby markets, and, secondarily, for distribution to the local trade. By 1927 consignment points utilized by one or more refiners had increased to the hundreds. The Institute eliminated a great many of these points and the decree enjoined such Institute action.

This phase of the case shifted the general emphasis from the Institute's favorite theme of open prices and non-discrimination to the proposition that the maintenance of these local stocks in such vast number was economic waste. The slight advantage to a refiner in increasing his local trade by the maintenance of local stocks ready for delivery, in small as well as large quantities, was of sufficient weight to incline one refiner to trail the other in establishing new storage points. Undoubtedly the increase in the number of these points had a spiral movement, and many of the points, although benefitting and conveniencing the local trade, could hardly be deemed essential to efficient, economical distri-

enable the fixation of prices; nor to limit the freedom of price movements in response to changing market conditions." Said Congressman Patman: "The bill is opposed to price fixing." S0 Cong. Rec. 7760 (1936). See also 80 Cong. Rec. 3116, 6286 (1936).

In regard to waiting periods, Congressman Patman said: "Prices may be changed as at present except prices shall not be changed for the sole and only purpose of granting a special favor or benefit to a favorite customer. A bona fide price may be changed at any time." 80 CoNG. Rec. 7761 (1936). "There is nothing in the bill that will hinder a man changing his price every day and every hour if his purpose is not to discriminate against a competitor." 80 CoNG. Rec. 8231 (1936).

In this connection, some of the language of $\$ 1$ (b) must be considered here, namely that, "nothing herein contained (the placing of the burden of proof on the alleged violator) shall prevent. 2 seller rebutting the prima facie case thus made by showing that his lower price ... . was made in good faith to meet the equally low price of a competitor, ..." This replaces analogous language in old $\$ 2$ of the Clayton Act which provided that "nothing herein contained $(\$ 2)$ shall prevent discrimination in price in the same or different communities made in good faith to meet competition." Obviously, a statute containing a provision of the latter character cannot be said to encourage price uniformity, especially in view of the fact that in actual operation this provision robbed the statute of any effectiveness, because discriminations (discounts) could be so easily justified. See Conference Report, H. R. REp. No. 2951, 74th Cong. 2d Sess. (1936). Hence, if the above-quoted provision of the Robinson-Patman Act has a like effect, any claim that the Act will result in price uniformity is entirely unfounded; however, there can be no doubt but that it was intended to have a much narrower scope and designed merely as a "procedural" rule of evidence. It was pointed out that meeting competition is "not set up . . . as an absolute bar to a charge of discrimination under 'the Act." In each case, it is "a question of fact . . . whether the competition to be met was such as to justify the discrimination given, as one lying within the limitations laid down by the bill ..." (id. at 7). 
bution. There was no apparent way to end the practice without concert of action. Individual action in attempting to restrict the number of points was ineffective in the face of competitive pressure to increase them.

The refiners insisted that they were thus performing storage functions that the distributors ought to furnish for themselves, and were merely rewarding loose methods involved in the distributors' failure to plan and provide for the needs of their customers a brief time in advance. They complained of the Court's holding that fixing the consignment service charge was a restraint of trade while, at the same time, deciding that the elimination of the points was injurious to the trade, thus clipping the restraint on consignments at both ends. Perhaps the Court felt, in the mood of the Trenton Potteries case, that the fixing of a fair price for a. beneficial service may itself be illegal.

There were a number of considerations involved in the conclusion of the trial court against the Institute's elimination of consignment points. One result of the Institute's move was to slam the door of opportunity in the face of the desk jobber, a man who had no greater wholesale establishment than a desk and a place to hang his hat and who was dependent upon these local storage stocks for his deliveries to the retail stores. Discrimination between localities was another consequence of the restraint. A city which has the stocks in storage for ready distribution may attract trade at the expense of neighboring cities without such stocks. While there were generally no substantial delays in the deliveries of sugar from refinery or central points, the existence of local stocks made them readily available to the local trade. Certain smaller distributors asserted an advantage in being able to procure a complete assortment of sugars without the risk of making commitments. The smaller distributor with little storage facilities of his own was favored, while at the same time the chain stores fell back upon this device by taking dribbling deliveries from day to day on their large purchase contracts. The distributor frequently avoided the purchase of carload lots, with its greater investment in sugar and in warehouse facilities, extensive storage, and the risk of deterioration-which is a considerable item in the sugar industry-by reliance upon the refiners' consignment points.

Long-term Contracts. The Court found that the Institute eliminated the sale of sugar on long-term contracts and condemned this action as an unreasonable restraint of trade.

A few such contracts assumed importance in the trade because of the peculiar structure of the sugar market. The average purchaser takes about a month's supply of sugar. The usual form of contract calls for delivery within thirty days. Price change announcements usually provoke sugar moves during the course of the month. However, prices in the sugar industry are of such a sensitive character, that a purchaser 
who can contract for sugar months in advance may be receiving and selling sugar at other than the going price at the time of delivery. This of course disturbs the market and throws a strain on the price system. There was thus not only a lowering of prices to the public in specific instances but also a tendency toward lower prices generally. Although there was substantial testimony to show a concerted elimination of longterm contracts, the defense urged that the finding was erroneous and that the industry would in fact be satisfied with open prices available to all. ${ }^{44}$ The court concluded as a matter of law that eliminating this form of contract restricted the commercial freedom of the refiners and contributed to preventing competitive fluctuations of price. The finding of fact itself was of greater significance as added evidence that the Institute's professed antagonism to discriminatory trade practices was a cloak for its concerted efforts to guard a price level.

Miscellaneous Restraints. Tolling contracts, under which the purchaser furnishes the raws and pays a service charge for the refining service, were restrained by the Institute, and the restraints were condemned. Again it was clear that the Institute's theory of non-discrimination was irrelevant and that the actual aim was the elimination of a minor impediment to uniformity of price. ${ }^{45}$

- The Institute forbade the acceptance of used bags returned by the customers. One customer, by quickly and carefully handling the commodity, preserving the bag and returning it, would reduce the cost of bags from 15 cents to a fraction of that amount. This item would run into thousands of dollars for a single purchaser. On the other hand, a number of the customers so used the bags that they were not fit for refilling. Thus, while there were distinct economies in permitting the re-use of bags, the system of allowances for used bag returns could be used by the refiner to grant a secret discount on a return of worthless bags. The restraint struck both the economic practice and the discriminatory one. Again the courts felt that the restraint had gone too far. ${ }^{40}$

The Institute adopted various rules having to do with transiting and diversion, water carriers, private charters, pool cars, and pool cargoes

44. Brief for Äppellants 172 . $^{\circ}$

45. It should be noted in passing that uniformity of price on standardized articles sold under similar conditions is compatible with the existence of free competition. Analysis should emphasize the standardization of the commodity sold, and the competitive structure of the market [cf. p. $254 \mathrm{infra}$ ] in which it was sold. Price uniformity at the market does not require a uniformity of delivered prices. FETTER, suppra note 9, at 333. At the trial the defense frequently urged that discrimination was involved wherever some purchasers lacked the facilities to enable them to take advantage of some normal service or mode of sale or delivery.

46. This practice if it is available to one purchaser and not to another may under $\$ 3$ of the Robinson-Patman Act be held a rebate and subject the seller to criminal penalties, or to a cease and desist order if held violative of either $\$ 1$ (a) or $\$ 1$ (c). 
and trucking. Most of them were disapproved, although largely of a regulatory and, to 'a certain extent, wholesome character, as generally tending to interfere with the business of third parties and the unrestricted flow of traffic. The fact of these minor trade rules of the Sugar Institute is intelligible only insofar as they were part of a comprehensive plan condemned in its general phases as an illegal restraint of trade. In another case, it may be, the courts will take a more cooperative attitude where an-industry seeks to eliminate small and genuinely annoying competitive practices.

Genteral Purposes and Good Faith. The Institute defended itself vigorously on grounds of its good faith. The district court, however, devoted itself primarily to an analysis of economic consequences of the Institute's practices. Based upon this study, it found that the purposes of the defendants in organizing and maintaining the Institute were: ${ }^{47}$

"To create and maintain a uniform price structure, thereby eliminating and suppressing price competition among themselves and other competitors; to maintain relatively high prices for refined, as compared with contemporary prices of raw sugar."

This approach was in accord with a consistent line of decisions to the effect that good intentions and perhaps some good results will not justify substantial restraints. ${ }^{48}$ Actual intent will not be ignored by the Court where the effect of an agreement is not manifest, or where conduct is equivocal, since it may be helpful in "the interpretation of facts and the prediction of consequences." 40 But this was one of the cases where the effects were apparent; stated intentions were regarded merely as "pious protestations and smug preambles" which intensified "distrust."

But the defense argued eloquently and at length that the purposes of the Institute were to avoid discriminations, to make all prices public, and to eliminate waste; and it paraded many imposing personages in the sugar industry to testify that stabilization of prices and enhance-

47. United States v. Sugar Institute, 15 F. Supp. 817, S90 (S.D. N. Y. 1934).

48. United States v. Trans-Missouri Freight Ass'n, 166 U. S. 290, 341 (1S97); .Standard Sanitary MIfg. Co. v. United States, 226 U. S. 20, 49 (1912); United States v. Union Pacific R. R., 226 U. S. 61, 93 (1912); United States v. Reading Co., 226 U. S. 324, 370 (1912); Thompson v. Cayser, 243 U..S. 66, 85 (1917); Paramount Famous Players Lasky Corp. v. United States, 2S2 U. S. 30 (1930); United States v. First National Pictures, Inc, 282 U. S. 44 (1930).

49. Swift \& Co. v. United States, 196 U. S. 375, 397 (1905); United States v. Union Pacific R. R., 226 U. S. 61 (1912); Chicago Board of Trade v. Uniled States, 246 U. S. 231 (191S); Appalachian Coals, Inc. v. United States, 285 U. S. 344, 372 (1933).

50. Cf. dissenting opinion of Mrr. Justice MreReynolds in Mfaple Flooring Ass'n v. United States, 268 U. S. 563, 587 (1925); Texas \& N. O. R. R. v. Brotherhood of Ry. \& Steamship Clerks, 281 U. S. 548, 559 (1930). 
ment of refiners' profits were negligible motives in comparison to the Sugar Institute's interest in spreading information, publishing prices, and preventing discriminations. They referred to the conferences which the organizers of the Institute had with the Department of Justice, and the Department's assistance in drafting the code, as further evidence of their intention not to restrain trade.

The emphasis placed by the defense on its relations with the Government, at the time of organizing the Institute, is of particular interest because of its practical importance in the future administration of the law. This is what happened: At the outset, the industry submitted its code to the Attorney General, who advised them that he saw "no basis which would require the institution of proceedings". Immediately certain members of the industry publicly described this as an "approval". The Attorney General pointedly corrected the statement, writing them that he had no authority to approve the plan. The Department reserved full right to proceed in court. Later the same Attorney General became doubtful as to the legality of phases of the plan. The succeeding Attorney General believed the plan illegal from the beginning and, after viewing it in actual operation and receiving complaints from injured parties, began an action to enjoin operations. In court the industry persistently claimed government approval as bearing upon its good faith, urging that it had not gone beyond the "approved" plan. The trial court not only found that the industry had not informed the Government of some of the restraints actually imposed, but also that much of the original code itself was bad. The Supreme Court's view was in accord. Such a record indicates the practical difficulties involved in the comment on abstract plans by the prosecuting agency, whose primary function is on the public side of the controversies so frequently arising from such plans. It is clear that qualifications expressed by the Department of Justice in its comment on a plan will be ignored by industry. ${ }^{51}$ The embarrassment of such action by the prosecuting agency is substantial, and the danger that the tentative opinion of the Department may have an undue persuasive influence on the courts is greater than the results of the Sugar Institute case indicate. ${ }^{52}$ Many business men would like some form of declaratory judgment in these cases to inform them in advance

51. In this connection see the Federal Trade Commission Trade Practice Conference, Rules for the Petroleum Industry and the decree in the United States v. Standard Oil Co. of Calif. et. al., N. D. Calif. Sept. 15, 1930; as to the Paramomnt case and the situation more generally, see Montague, Proposals for the Revision of the Anti-Trust Lazus (1932) Syirposiuac on tee Federal Anti-Trust Laws, C. C. H. 23, 29.

52. Cf. United States v. United States Steel Corp., 251 U. S. 417 (1920); United States v. Southern Pacific Co., 259 U. S. 214, 239 (1922); United States v. General Elec. Co., 15 F. (2d) 715 (N. D. D. Ohio 1925), aff'd., 272 U. S. 476 (1926); Legis. (1932) 45 HaRv. L. Rev. 566, 570. 
as to the legality of their plans of combination. But abstract plans are not always identical with actual operations. And a judgment as to the legality of a trade association plan requires a careful consideration of many detailed facts as well as a prophetic vision as to its actual effect on commerce. There is no simple test of legality under the anti-trust laws $;^{53}$ the courts view a trade practice suspected of illegality as best they can in terms of its facts, appraise what seem to be its economic consequences, consider the convenience and ordinary routine of trade, and decide the issue without recourse to clear standards, or simple tests. The history of the Sugar Institute and its relations with the Department of Justice illustrates the danger of official opinions in advance of the trade's actual experience with its association's plan.

This brief inquiry into the activities of the Sugar Institute, against their business background, and against the background of statutory and non-statutory law of restraint of trade, suggests several of the crucial weaknesses of the anti-trust laws. The laws to protect competition have never been considered by Congress as an organic whole, designed to

53. In this connection a word of warning should be recorded concerning the growing assumption that the courts apply a price-fixing test in determining the legality of trade agreements. See Kirsch, Trade Associntrons, TheIr Legar Aspects (1923) 185; Handler, The Singar Institute Case and the Present Stalus of the Anti-Trist Laws (1936) 36 CoL. L. Rev. 1, 5; ef. Jaffe and Tobriner, The Legality of Price-Fixirg Agreements (1932) 45 HARv. L. REv. 1164. This tendency is due to the fact that the term "price fixing" has been loosely used to include agreements impeding price competition or fixing individual elements of ultimate price. There has been such a general failure to describe restraints precisely that the danger has arisen that important restraints of trade may be overlooked by reason of the emphasis on price fising. The importance of the Sugar Institute case in clarifying this point should not go unnoticed.

Prior to the Institute, list prices of sugar were substantially uniform, and there were only moderate variations in the actual selling prices of the different refiners. After the Institute, prices were in fact uniform and were sufficiently higher "to negate the inference of free competition." The Court concluded that the dominant purposes included the maintenance of a relatively high uniform price structure. NNeither court feit that the basic price was fixed concertedly [56 Sup. Ct. 629, 634 (1936); 15 F. Supp. $\$ 17,890$ (S.D.N.Y. 1934)] and both agreed that there was substantial competition upon the basic price itself. Nevertheless, the Court condemned a number of agreements bearing upon various phases of the price structure but individually and collectively falling short of an express or implied agreement to fis the price of sugar.

It is thus apparent that restraints of trade may be illegal for their effect on production, or territory, or the status of distributors, or transportation routes, or the shifting of trade from one vicinity to another-all without being substantially equivalent to price fixing. Future price reporting, with an agreement not to deviate, may be illegal, indeed, because of its effect on prices, and yet fall far short of price fixing. Restraints may be illegal because of their influence on the profit level without even affecting price. The assumption that price fixing is a necessary term of an illegal restraint seems to lead only to confusion; there is nothing to be gained in analysis or prediction by such an attempt to simplify the test of legality. 
implement a clearly formulated policy. They have grown up piecemeal, concrete as to practices which touched the imagination of Congress as dangerous, or pressed hard on the toes of a potent pressure group; but vague in great areas where successful administration is impossible without more explicit standards. While courts sympathetic to the purposes of anti-trust legislation might have made the present anti-trust laws more effective, the statutes have had a long and familiar history of judicial emasculation; it is now clear that progress depends on statutory change, and not on growth within the Rule of Reason.

The history of the Sugar Institute, ${ }^{54}$ and a view of its operation, dramatize several issues which should be basic elements in an anti-trust policy. The first is the importance of the market structure within which a suspected violation of the anti-trust laws takes place. The economic results of trade association practices are different in a market of few sellers than in a market of many sellers, and the statutes should be framed to recognize differences of policy appropriate to the differences between perfect and monopolistic competition. Thus, a trade practice, like price discrimination, may represent a monopolistic tendency, in a market which is in the main open, or a competitive influence on the restrictive policy of a more fully monopolized market; the anti-trust laws treat the two situations identically. Another issue, the importance of which has been greatly increased by the passage of the Robinson-Patman Act, concerns the right of a combination to restrain activities which may be illegally discriminatory. In view of the scope of the Act, the limitations on the powers of trade associations in this respect need express clarification; and Congress may well undertake to set legal boundaries for the several more significant trade association activities. And finally legislative safeguards are needed to insure that the application of the anti-trust laws to trade associations does not go the way of the merger cases. This can best be effected, of course, by legislation remedying the notorious failure of the anti-trust laws to prevent monopolistic mergers. Pending the enactment of effective legislation, the Sugar Institute case may well be used as the basis for an intelligent adaptation of the antitrust laws to the economic problems of collective action by business groups. Aside from a somewhat dubious treatment by the Supreme Court of one aspect of the Sugar Institute's information service, and a failure adequately to articulate first principles the Sugar Institute case is the best available guide to the anti-trust laws, and the most comprehensive-and most useful-collection of legal and factual materials in the field. Although the case may not require the trust laws to grow along the lines indicated above, it will not prevent such a growth, and in many. ways looks forward to one.

54. With the closing of the Institute, this history has ended. N. Y. Times, Nov. 19, 1936, p..39, col. 5 . 